Stachow, Mary Ann. "Do you understand what you are reading?" (Acts 8:30): a historical-critical reexamination of the pericope of Philip and the Ethiopian (Acts 8:26-30). Ph.D., Catholic U. of America, 1998. 981213.

\section{Social Work}

Dufite-Bizimana, Penninah. Getting back to the garden: rethinking child welfare in Uganda. Ph.D., U. of Toronto (Can.), 1997. NQ27915.

\section{Sociology}

Altman, Reed Adam William. Participatory methods of community development and organizational linkage: the case of community development organizations in Kenya. Ed.D., North Carolina State U., 1998. 9909452.

Assoumou, Alfred. Mariage à la dot chez les Fang du Gabon. Ph.D., U. Laval (Can.), 1998. NQ31481.

Ball, Patrick Donnell. Liberal hypocrisy and totalitarian sincerity: the social and ideological origins of the national nongovernment human rights movement in El Salvador, Pakistan, and Ethiopia. Ph.D., U. of Michigan, 1998. 9828447.

Barry, A. Amadou B. Violences collectives en Afrique. Ph.D., U. de Montreal (Can.), 1998. NQ32579.

Bonner-Fenty, Shirley Ann. Paleolithic anatomically modern ancestral African Khoisan migrated to Asia and America as indicated by genetic, cultural and linguistic evidence. Ph.D., State U, of New York at Buffalo, 1998. 9905243.

Dagogo, L. D. Traditional birth attendant versus the hospital: a study of factors which contribute to the choices made by pregnant women in obstetric services utilization in Port-Harcourt, Nigeria. Ph.D., Southampton (U.K), 1997. BL.

Ekwa Ngui, Mathieu. Temps social et développement en milieu rural de la province du Woleu-Ntem [Gabon]. Ph.D., U. Laval (Can.), 1998. NQ31491.

El-Rahman, A. G. E. A. Privatisation in Egypt, management and welfare implications for employers. Ph.D., Manchester (U.K.), 1997.

Ettyang, Linus Ikapel Akisa. Exogenous covariates of desire for another child: the Kenyan experience. Ph.D., U. of Southern California, 1998. 9835049.

Gadio, Coumba Mar. Women's changing roles, issues, and decision making: the case of Lebou-Wolof women farmers in Thieudeme [Senegal]. Ph.D., Ohio State U., 1998. 9833978.

Gan, Alia. Agricultural restructuring, household practices and family farm differentiation: a case study of the region of Zaghouan [Tunisia]. Ph.D., Cornell U., 1998. 9831082.

Madhavan, Sangeetha. Collaboration and conflict among women in rural Mali: effects on fertility and child survival. Ph.D., U. of Pennsylvania, 1998. 9913494.

Magqwaka, M. Lifting South African townships. Ph.D., York (U.K.), 1997. BL.

Mickleburgh, A. R. Relevance of marriage for Ganda women in Bwaise, Kampala, Uganda. Ph.D., Cambridge (U.K.), 1998. BL.

Ndumbaro, Laurean Josephat Philomena. Learning and policy change: the case of Swedish International Development Cooperation Agency (SIDA) 1980-1995 [Tanzania]. Ph.D., U. of Florida, 1998. 9906001.

Nyblade, Laura Christine. HIV counseling and testing in a rural Ugandan population. Ph.D., U. of Pennsylvania, 1998. 9913251.

Obiero, Walter Obungu. Educational expansion and the emerging fertility transition in Kenya. Ph.D., U. of Michigan, 1998. 9909958.

Okafor, Chukwudi Hezy. Social inequality in living conditions, health, and quality of life in South Africa: development policy challenges and prospects. Ph.D., Iowa State U., 1998. 9911630.

Patterson, Rubin. Political economy of state export capital to Southern Africa and East Asia between 1946 and 1989. Ph.D., Howard, 1992. 9911345.

\section{Statistics}

Fofack, Hippolyte Lekeulem. Distribution of parallel market premium under stable alternative modeling. Ph.D., American U., 1998. 9908152.

\section{Theater}

Cavano, Arthur Thomas. Death and pagan heroes in the twentieth century: a comparison of Wole Sonyinka's "Death and the King's Horseman" with W. B. Yeats' "The Death of Cuchulain" [Nigeria]. Ph.D., Florida State U., 1998. 9911441.

Okafor, M-B. C. Theatre of life: rituals, transition and progression among the Igbo [Nigeria]. Ph.D., Plymouth (U.K.), 1998. BL.

\section{Theology}

Muteba-Magalu, Fulgence. De l'aporétique à l'assomption auto-conctructive: l'enjeu des pratiques post-missionaires d'auto-réalisation de l'église catholique au Zaïre (1960-1995). Ph.D., U. de Montreal (Can.), 1998. NQ33065.

Pemberton, C. M. Feminism, inculturation and the search for a global Christianity: an African example: the circle of concerned African women theologians. Ph.D., Cambridge (U.K.), 1998. BL.

Urban \& Regional Planning

Majale, M. M. Settlement upgrading in Kenya: the case for environmental planning and management strategies. Ph.D., Newcastle upon Tyne (U.K.), 1998. BL.

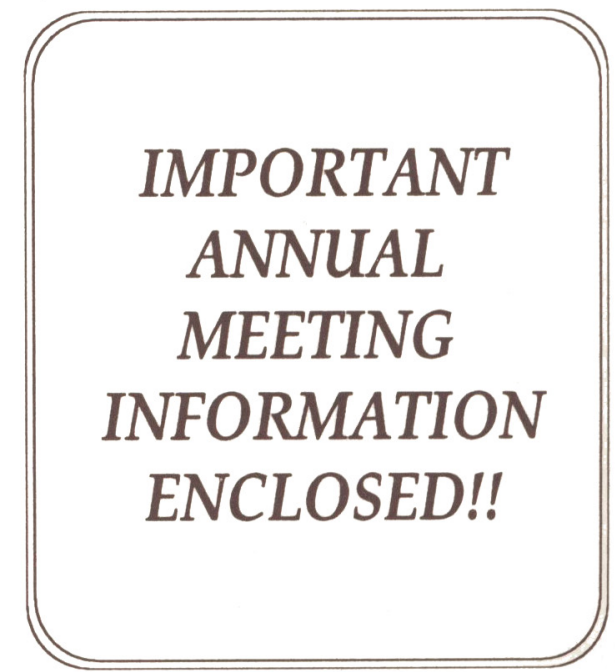

ISSN 0278-2219

African Studies Association

Rutgers University

Douglass Campus

132 George Street

New Brunswick, NJ 08901-1400
NON-PROFIT ORG
U.S. POSTAGE
PAID
ATLANTA, GA
PERMIT NO. 1689

